\title{
Peningkatan Kapasitas Petani Muhammadiyah dalam Seleksi Benih pada Budidaya Padi System of Rice Intensification
}

\author{
Increasing the Capacity of Muhammadiyah Farmers in Seed Selection in System of Rice \\ Intensification Rice Cultivation
}

Gatot Supangkat Samidjo*
Agung Astuti
Mulyono
Department of Agrotechnology,
Universitas Muhammadiyah
Yogyakarta, Bantul, Special Region
of Yogyakarta, Indonesia
email: supangkat@umy.ac.id
Kata Kunci
Direct learning
Metode larutan garam
Seleksi benih
SRI
Keywords:
Direct learning
Salt selection method
Seed selection
SRI

\begin{abstract}
Abstrak
Produksi padi di petani Muhammadiyah Godean masih rendah sekitar 5 ton/ha. Salah satu permasalahannya adalah penggunaan benih yang terlalu tua, daya tumbuhnya rendah sehingga memerlukan benih dalam jumlah yang banyak. Solusinya adalah diberi pemahaman dan ketrampilan tentang seleksi benih menggunakan larutan garam, sehingga diperoleh benih yang bernas, daya tumbuhnya tinggi dan efisien. Tujuan dari pemberdayaan petani Muhammadiyah Godean ini untuk meningkatkan pengetahuan dan ketrampilan tentang seleksi benih menggunakan larutan garam pada budidaya padi System of Rice Intensification (SRI). Metode Direct Learning diterapkan dalam implementasi program. Kegiatan yang dilakukan, meliputi penyuluhan, pelatihan dan pendampingan selama seleksi benih, pengujian daya tumbuh, dan kualitas benih. Hasil evaluasi menggunakan pre dan post test menunjukkan bahwa 53\% petani sudah pernah mengetahui metode seleksi garam, namun belum bisa melakukannya (53\%) dan sangat ingin belajar (80\%). Setelah dilakukan penyuluhan ada peningkatan pemahaman $47 \%$. Hasil program menyatakan semua petani menjadi paham (100\%) dan dapat menyeleksi benih dengan metode larutan garam, serta $73 \%$ merasa mudah melakukannya. Budidaya padi SRI dengan tahapan awal seleksi benih dengan metode seleksi larutan garam dapat diperoleh efisiensi benih sekitar $60-75 \%$.
\end{abstract}

\begin{abstract}
Rice production in Muhammadiyah Godean farmers is still low at around 5 tons/ha. One of the problems is the use of seeds that are too old, the growth power is low, so it requires large amounts of seeds. The solution is to be given the understanding and skills in seed selection using a salt solution so that the seeds are pithy, have high growth power, and are efficient. The purpose of empowering Muhammadiyah Godean farmers is to increase their knowledge and skills regarding seed selection using the salt solution in System of Rice Intensification (SRI) rice cultivation. The Direct Learning method is applied in program implementation. The activities carried out include counseling, training, and assistance during seed selection, testing for growth power, and seed quality. The evaluation results using pre and post-tests showed that $53 \%$ of farmers had already known the salt selection method but had not been able to do it (53\%) and were very eager to learn (80\%). After counseling, there was an increase in understanding of $47 \%$. The program results stated that all farmers understood (100\%) and could select seeds using the salt solution method, and $73 \%$ found it easy. SRI rice cultivation with the initial stages of seed selection with the salt solution selection method can be obtained seed efficiency of about $60-75 \%$.
\end{abstract}

\section{PENDAHULUAN}

Aktivitas penduduk di Bumi ini, tidak terkecuali Indonesia sangat tergantung pada bahan pangan utama yakni beras. Diperkirakan, 90\% produksi beras dunia berasal dari Asia dengan total produksi pada tahun 2010 sebesar 696 juta Ton. Jumlah konsumsi beras berbeda untuk setiap negara dan umumnya dipengaruhi oleh jumlah penduduknya (Samidjo, 
2016). Perubahan iklim global saat ini dapat mengakibatkan ancaman krisis pangan pada hampir semua negara/bangsa, termasuk negara-negara yang mengekspor berasnya ke Indonesia. Pada umumnya, ekspor beras yang dilakukan oleh negara produsen beras dunia hanya berkisar $7 \%$ dari total produksi dengan alasan pemenuhan konsumsi dalam negeri lebih dipentingkan (Hermawan, 2013). Negara-negara pengekspor beras cenderung mengurangi jumlahnya karena produksinya juga cenderung menurun akibat perubahan iklim dan bencana yang terjadi (Samidjo, 2016).

Ilustrasi saat ini, konsumsi beras nasional berkisar $139 \mathrm{~kg} / \mathrm{kapita} / \mathrm{tahun}$, misal penduduk Indonesia saat ini 250 juta maka kebutuhan beras nasional sebesar 34,750 juta ton. Berita terkini diperkirakan konsumsi beras per bulan mencapai 3 juta ton, jadi dalam setahun mencapai 36 juta ton. Sementara itu, produksi padi tahun 2010-2014 berurutan 66.469.394 ton, 65.756.904 ton, 69.056.126 ton, 71.279.709 ton, 70.846.465 ton Gabah Kering Panen (GKP) setara dengan beras 37.222.860,64 ton, 36.823.866,24 ton, 38.671.166,66 ton, 39.916.637,04 ton, dan 39.674.020,4 ton. Data itu menunjukkan adanya surplus 2 - 5 juta ton, namun untuk jangka panjang belum menjamin kecukupan pangan. Rasio ketersediaan pangan-beras terhadap kebutuhan konsumsinya cenderung semakin kecil dikarenakan jumlah penduduk yang terus meningkat, proses produksi tanaman seringkali terganggu karena perubahan iklim dan organisme pengganggu tanaman (OPT) serta areal tanam yang cenderung menurun (Arifin, 2015). Pilihan untuk mengatasi hal itu maka dilakukan impor beras dari negara lain, seperti Thailand dan Vietnam. Namun, cara tersebut menjadikan ketergantungan dan riskan baik secara ekonomi, sosial, budaya dan politik sebagai negara yang berdaulat (Hermawan, 2013). Untuk mengatasi adanya ketergantungan dengan negara lain maka cara yang tepat yakni peningkatan produktivitas tanaman dan produksi pangan dalam negeri. Perbaikan teknologi budidaya padi merupakan cara yang dapat dilakukan untuk meningkatkan produktivitas dan produksinya (Mayrowani \& Ashari, 2011). Salah satu teknologi yang potensial untuk tujuan itu yakni teknologi System of Rice Intensification (SRI).

Awal mula teknologi SRI ditemukan dan diterapkan di Madagaskar oleh Fr Henri de Laulani pada tahun 1983 kemudian dikenalkan dan dikembangkan lebih lanjut oleh Association Tefy Saina (ATS). Para petani didampingi oleh ATS dalam penerapan Teknologi SRI dan terbukti mampu meningkatkan hasil panen padi, dari 2 ton/Ha menjadi 8 ton/Ha (SRI International Network and Resources Center, 2015). Implementasi teknologi SRI di beberapa negara dapat mencapai hasil GKP sekitar 10 ton/Ha. Di beberapa daerah di Indonesia cukup beragam. Kabupaten Bandung dilaporkan 8 - 10 ton/Ha GKP (SRI-Organik), Tasikmalaya rata-rata 10,43 ton/Ha, Karawang dilaporkan lebih dari 6 - 7 ton/Ha GKP, Subang mencapai 9 ton/Ha, Sukabumi dilaporkan berkisar 6,5 ton/Ha, Cianjur mencapai 7 - 8 ton/Ha (Adrianto et al., 2016). Di Indonesia, teknologi SRI diterapkan dan dikembangkan di wilayah Jawa Barat yang dikenal dengan budidaya padi yang ramah lingkungan kemudian diadopsi oleh Pemerintah untuk melengkapi teknologi Pengelolaan Tanaman Terpadu (PTT). Dikatakan oleh Purwasasmita dan Sutaryat (2014) bahwa teknologiSRI merupakan teknik rekayasa mikrobioreaktor tanaman dan terbukti mampu meningkatkan hasil dari 4 - 5 ton/Ha menjadi 8 - 12 ton/Ha, hemat air sebanyak 2.700 $3.000 \mathrm{~L} / \mathrm{kg}$ menjadi 800 - $1000 \mathrm{~L} / \mathrm{kg}$ padi, hemat benih dari $30 \mathrm{~kg} / \mathrm{Ha}$ menjadi $3-5 \mathrm{~kg} / \mathrm{Ha}$ dan menghasilkan beras yang sehat (bebas residu senyawa berbahaya). Prinsip dasar dari Teknologi SRI, yaitu seleksi benih jitu, bibit muda umur 7 - 9 hari, satu bibit tiap lubang (efisien jumlah bibit), irigasi Tepat kebutuhan (efisien air), dan penggunaan pupuk organik (efisien hara) (Samidjo, 2017). Bibit merupakan material yang sangat penting dalam penerapan teknik budidaya tanaman. Bibit akan menentukan tingkat keberhasilan suatu usahatani, karena bibit yang baik akan menghasilkan pertumbuhan dan produktivitas tanaman yang baik dan tinggi. Bibit yang baik sangat ditentukan oleh kualitas benih yang digunakan. Benih yang berkualitas dan memiliki vigorisitas tinggi dapat diperoleh dengan cara pemilihan benih yang tersedia (Aldillah, 2016).

\section{METODE}

Metode yang diterapkan yakni Sustainable and Together Learning. Metode ini dilaksanakan secara sistematis dalam suatu medium pembelajaran secara langsung di lapangan. Beberapa teknik pengelolaan program yang diterapkan, antara lain PRA (Participatory Rural Appraisal), FGD (Focus Group Discussion), praktik belajar (practical learning), dan belajar pengalaman 
baik (best practice learning). Adapun implementasi dari metode yang dipilih dilakukan secara bertahap, meliputi observasi, sosialisasi, koordinasi dengan tim, mitra, dan pihak terkait, pelaksanaan program-kegiatan, dan evaluasi dan keberlanjutan. Semua program dan kegiatan yang telah direncanakan bersama mitra dilaksanakan secara sistematis dan terorganisasi dengan baik melalui komunikasi intensif dengan mitra.

\section{HASIL DAN PEMBAHASAN}

Hasil wawancara dan pengamatan langsung di lapangan menunjukkan bahwa hasil padi masih rendah yaitu 5 ton/Ha. Rendahnya hasil tersebut disebabkan salah satunya oleh penggunaan benih yang terlalu tua sehingga daya tumbuhnya rendah, dan cara pembibitan yang kurang tepat sehingga bibit mengalami kekuningan/stress. Berdasarkan hasil ini diperlukan pengenalan dan pemahaman terhadap teknologi budidaya padi yang efektif dan efisien, terutama dalam hal pemilihan benih. Benih ini menjadi sarana produksi usahatani utama, karena itu penggunaan benih berkualitas sangat dianjurkan.

Kegiatan yang akan dilaksanakan dalam program pemberdayaan disosialisasikan kepada Mitra, yakni petani yang tergabung dalam Koperasi Agro Sejahtera Muhammadiyah (KOPASAMU). Sosialisasi dilakukan tatap muka secara online atau dalam jaringan (daring), mengingat adanya pandemi Covid-19. Tim pengabdi dan mitra menyepakati kegiatankegiatan yang dilaksanakan, yaitu pengenalan teknik budidaya padi SRI, pelatihan metode seleksi benih SRI, dan praktik metode seleksi, dan evaluasi dan keberlanjutan. Teknik budidaya padi SRI, termasuk di dalam metode seleksi benih secara umum dikenalkan kepada para petani. Penyuluhan dilaksanakan secara online atau daring yang diikuti oleh 13 orang petani binaan KOPASAMU.

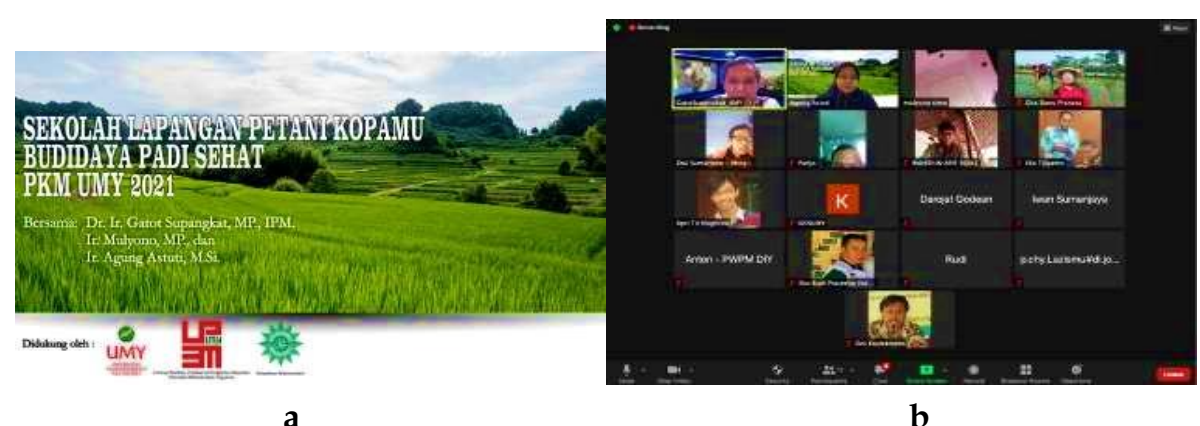

Gambar 1. Materi presentasi (a) dan kegiatan pengenalan teknik budidaya padi SRI secara online (b)

Beberapa petani telah mengenal teknik budidaya padi-SRI, namun banyak yang belum mengetahuinya. Pada sesi diskusi, banyak petani yang bertanya dan konfirmasi atas pengalamannya dalam budidaya padi, khususnya dalam penggunaan dan pemilihan benih. Antusiasme dari para petani dikarenakan banyak yang belum mengetahui tentang teknik budidaya padi-SRI berdasarkan pengalaman dalam melaksanakan budidaya padi selama ini.
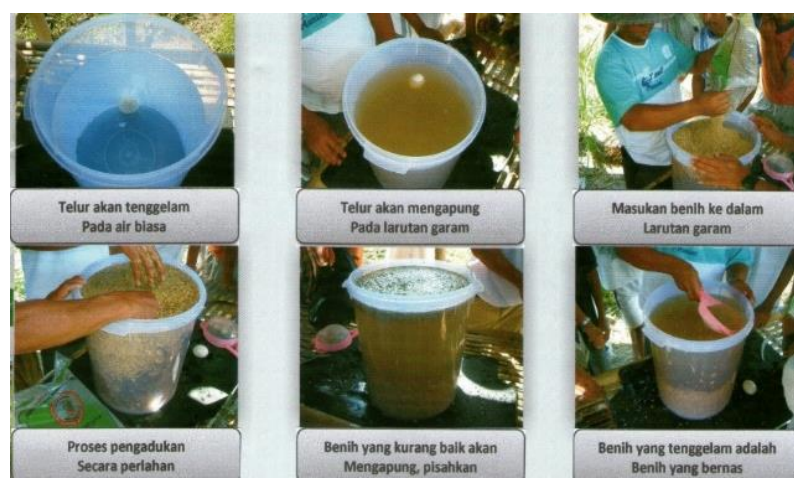

Gambar 2. Metode seleksi benih berdasarkan teknik budidaya padi-SRI (Sumber: Dokumen Nagrag Organic SRI Center, Sukabumi) 
Gambar 2 memperlihatkan bahwa metode seleksi benih metode SRI tidak rumit dan sulit, namun karena petani belum tahu, sehingga seolah-olah tekniknya rumit. Teknik ini efektif untuk menentukan benih yang bernas dan layak digunakan sebagai bahan tanam. Petani dilatih seleksi benih padi dengan menggunakan larutan garam didampingi oleh tim pengabdi. Seleksi benih padi menggunakan larutan garam, akan diperoleh benih bernas yang dengan tenggelamnya benih dalam larutan garam. Di samping itu, larutan garam juga bermanfaat sebagai perlakuan awal untuk meminimalisasi tanaman padi terserang penyakit yang disebabkan oleh jamur yang terbawa oleh benih padi (Nuryanto, 2018).

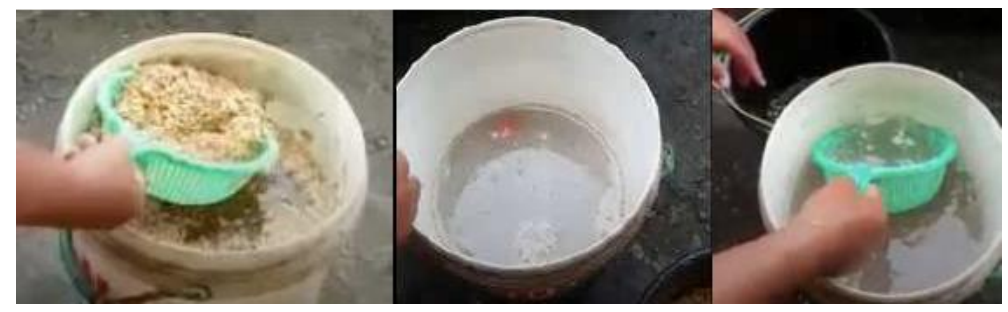

Gambar 3. Praktik seleksi benih metode SRI oleh petani dan benih bernas hasil seleksi (tenggelam)

Sosialisasi, penyuluhan, dan praktik telah dilaksanakan secara bersama dengan mitra pengabdian. Tanggapan petani terhadap program dan kegiatan pengabdian disajikan dalam Tabel I. Hasil evaluasi menggunakan pre dan post tes menunjukkan bahwa $53 \%$ petani sudah pernah mengetahui metode seleksi benih dengan air garam, namun belum bisa melakukannya (53\%) dan petani sangat ingin belajar (80\%). Setelah dilakukan penyuluhan ada peningkatan pemahanan 47\%. Tabel I memperlihatkan semua petani menjadi paham (100\%) dan dapat menyeleksi benih dengan larutan garam, serta $73 \%$ merasa mudah melakukannya.

Pendapat petani binaan koperasi bahwa dengan menerapkan seleksi benih menggunakan larutan garam ini (metode SRI) akan menghemat benih yang digunakan. Umumnya, untuk tanam dengan luasan lahan yang sama seluas $1000 \mathrm{~m}^{2}$ diperlukan $6 \mathrm{~kg}$ benih, namun dengan seleksi garam-metode SRI ini hanya diperlukan $1 \mathrm{~kg}$ benih yang bernas, sehingga ada efisiensi kebutuhan benih sekitar $60-76 \%$.

Tabel I. Respon petani sebelum dan sesudah implementasi program dan kegiatan

\begin{tabular}{lcccccc}
\hline \multirow{2}{*}{ Seleksi Benih-SRI } & \multicolumn{3}{c}{ Sebelum } & \multicolumn{3}{c}{ Sesudah } \\
\cline { 2 - 7 } & Ya & Ragu & Tidak & Ya & Ragu & Tidak \\
\hline Tahu metode seleksi & 53,33 & 6,67 & 40 & 100 & 0 & 0 \\
Dapat menyeleksi & 33,33 & 13,33 & 53,34 & 100 & 0 & 0 \\
Ingin menyeleksi & 80 & 6,67 & 13,33 & 100 & 0 & 0 \\
Tingkat kesulitan seleksi & 13,33 & 53,33 & 33,34 & 26,67 & 0 & 73,33 \\
\hline
\end{tabular}

\section{KESIMPULAN}

Hasil program menyatakan semua petani menjadi paham (100\%) dan dapat menyeleksi benih dengan metode larutan garam, serta 73\% merasa mudah melakukannya. Budidaya padi SRI dengan tahapan awal seleksi benih dengan metode seleksi larutan garam dapat diperoleh efisiensi benih sekitar $60-75 \%$.

\section{UCAPAN TERIMA KASIH}

Manuskrip ini merupakan luaran dari Program Pengabdian kepada Masyarakat (Abdimas) skema Kemitraan Masyarakat (PKM) dengan sumber pendanaan internal dari Universitas Muhammadiyah Yogyakarta (UMY) tahun Akademik 2020/2021. Implementasi program dilaksanakan Bersama Mitra Abdimas, yaitu KOPASAMU. Untuk itu, Tim Abdimas mengucapkan terima kasih dan penghargaan kepada Pimpinan UMY, Pimpinan KOPASAMU, dan para petani Muhammadiyah. 


\section{REFERENSI}

Adrianto, J., Harianto, Hutagaol, M.P. 2016. Peningkatan Produksi Padi melalui Penerapan SRI (System of Rice Intensification) di Kabupaten Solok Selatan. Jurnal Agribisnis Indonesia (Journal of Indonesian Agribusiness). 4(2):107122. https://doi.org/10.29244/jai.2016.4.2.107-122

Aldillah, R. 2016. Kinerja Pemanfaatan Mekanisasi Pertanian Dan Implikasinya Dalam Upaya Percepatan Produksi Pangan Di Indonesia. Forum Penelitian Agro Ekonomi. 3(2):163-177. http://dx.doi.org/10.21082/fae.v34n2.2016.163-171

Arifin. 2015. Pengantar Ekonomi Pertanian. Bandung: Mujahid Press

Hermawan, I. 2013. Analisis Perdagangan Beras Dan Ketahanan Pangan Di Negara-Negara Asia Tenggara. Jurnal Politica : Dinamika Masalah Politik Dalam Negeri dan Hubungan Internasional. 4(2):157-195. http://dx.doi.org/10.22212/jp.v4i2.320

Mayrowani, H., Ashari. 2011. Pengembangan Agroforestry untuk Mendukung Ketahanan Pangan dan Pemberdayaan Petani Sekitar Hutan. Forum Penelitian Agro Ekonomi. 29(2):83-98. http://dx.doi.org/10.21082/fae.v29n2.2011.8398

Nuryanto, B. 2018. Pengendalian Penyakit Tanaman Padi Berwawasan Lingkungan Melalui Pengelolaan Komponen $\begin{array}{llll}\text { Epidemik. Jurnal Penelitian dan Pengembangan } & \text { Pertanian. }\end{array}$ http://dx.doi.org/10.21082/jp3.v37n1.2018.p1-8

Purwasasmita, B., Sutaryat, A. 2014. Padi SRI Organik Indonesia. Jakarta: Penebar Swadaya

Samidjo, G.S. 2017. Eksistensi Varietas Padi Lokal pada Berbagai Ekosistem Sawah Irigasi: Studi di Daerah Istimewa Yogyakarta. Planta Tropika: Jurnal Agrosains. 5(1):34-41. https://doi.org/10.18196/pt.2017.069.34-41

Samidjo, G.S. 2016. Panduan Praktis: Teknologi Budidaya Padi SRI dengan Pupuk Organik Cair. Yogyakarta: Prakasita Sekar Mataram

SRI International Network and Resources Center. 2015. Summary of SRI in Madagascar. http://sri.ciifad.cornell.edu/countries/madagascar/index.html 